But the chief aim of the science-art classes will be to encourage a purstit of scientific truth for its own sake, not for the sake of displaying talent in making beautiful drawings to be praised for them, nor for the money to be got for them when drawn, but, simply and only, for the sake of the TRUTH, which will yield us pure and incessant pleastre all our lives, and engender a sincere reverence for the Creator who has clothed his truths in wrappages of beautiful blo:soms, and pure crystals, and opalescent clouds; in wrappages, too, which appear mean and even ugly, but they are wrappages only; even sin-that, too, is a wrappage, and looks very ugly, and is very revolting, but it covers some good, some truth which lies hid in cvery human heart, if we will only seek to find it.

There is a vast amount of real art-power unutilised, and so wasted, in our public schools, through narrowness of purpose in the teaching. It has been so amongst ourselves, though what we have done we have done thoroughly. We have laid a sound foundation in close observation of beautiful form and acquisition of technical power in representing it. In adding to it these nature-drawing classes, we have nothing to unteach. The field of work is simply widened that the power may be the more effecttally utilised with more pleasure and with greater profit to the studert, not only while at school, but as a pursuit in after life, and possibly drawing many from pleasures which are ugly, coarse, bad, and fleeting. This is a view of nature-drawing which parents might think about not without profit to their children. The pursuit of scientific truth, whether in the shape of landscapeart or of science-art, is a very noble pursuit, a very lasting pleasure; besides which science and art cannot fail to be mutually benefiteri, mutually advanced, in the long run, by such a conjunction as this, for indeed art loses her right hand when divorced from science, and science loses her right hand when divorced from art.

\section{UNIVERSITY AND EDUCATIONAL} INTELLIGENCE

CAMBRIDGI. - The following have been elected to the General Board of Studies:-Mr. II. M. Taylor, by the Special Board for Mathematics; Prof. Liveing, by the Special Board for Physics and Chemistry; Dr. Vines, by the Special Board for Biology and Geology.

The election to the Cavendish Professorship of Experimental Physics will take place on December 22. The endowment of the professorship is $850 l$. a year.

The provision of 100 additional microscopes for the Biology Schools has been sanctioned, and a small charge will be made to students for their use.

Mr. C. T. Hcycock, of King's College, has been approved as a Tencher of Chemistry, under the regulations for medical study.

The Syndicate for obtaining plans for a Geological Museum and Chemical Laboratory has becn re-appointed.

Clarc College offers to give scholarships of from $40 \%$ to $60 \%$. for Natural Science by examination, beginning March 19 next. The subjects will be Chemistry and Chemical Physics, Botany and Geology. A fortnight's notice will be required. Candidates, who must be under ninetecn on the day of examination, must also pass in Flementary Latin, Greek, and Mathematics.

It is announced that in the next Fellowship election at St. John's College (November 2, I885) regard will be paid to candidates' uriginal disseriations or other writings, the candidates to be prepared to be examined in the subject-matter of the same. Canclidates may also be examined in spccial subjects chosen by themselves, provided they give full and precise information re garding such subjects not later than June $x$. The performance of the candidates in the University and other examinations will be regarded.

\section{SCIENTIFIC SERIALS}

Fournal de Physique, October 1884. -The constitution and origin of group B in the solar spectrum, by M. L. Thollon (one plate).-On the colour of water, by M. J. L. Soret.-The effect of the electrical state of the surface of a liquid on the maximum vapour-tension of the liquid in contact with the surface, by $\mathrm{M}$. $\mathrm{R}$. Blondlot (one figure). - On the measurement of the maxima and minima electromotive forces in cells with a single electrolyte, by M. Emile Reynier (two figures). - Standard cell for the measurentent of electromotive forces, by M. Emile Reynier.On the chemical theory of accumulators, by M. Emile Reynicr. -On the electrolysis of solid glass, by E. Warburg.

Foumal of the Russian Physico-Chemical Sosiely (Physical Section), vol. xv., i 883 . - On an air-calorimeter, by N. Hesehus. - On a differential air-calorimeter, by W. Preobragenski,-On the eritical temperature of isomerides and bodies belonging to the same homologous series, by A. Nadejdine. - New applica tion of Carnot's theorem, by B. Sresnewsky. - On an algebraic transformation and its applications to mathematical physics, by by N. Slouguinoff--On the focal properties of diffracted rays, by M. Mertching.-On the peculiar properties of caontchouc, by $N$. Hesehus.-Method of determining the mean tint of a multi-coloured surface, by Th. Petronchewsky. - On the cause and the law of the change of electrical resistance of selenium by the action of light, by.N. Hesehus.-On the relation between the magnetic moment of a bundle of iron wire, its mass, and the diameter of the constituent wires, by P. Bakmetieff.-Note on organ-pipes, by P. Bakmetieff. -On some phenomena of permanent magnetism, by $P$. Bakmetieff.-On the luminous phenomena accompanying electrolysis, by N. Slouguinoff. - On the theory of gratings traced on curved surfaces.

Fioyal Academy of Belgium, Nos. 9 and ro, r884.-Among other communications is a paper by Dr. J. MacLeod describing some interesting particulars respecting the structure and homologies of the anterior intestine of the Arashnides. In the Phalansides he has found a gland of the same nature and function as the coxal glands recently described by Prof. E. Ray Lankester as belonging to the Limules, the Scorpionides, and the Arancides tetrapneumones. In the culs-de-sac, moreover, of the male gland of the Trombidizm holosericeum, he has found, in all the individuals cxamined by him, ovules situated between the mother-colluies of the spermatozoirles, though there was no question there of a functional hermaphroditism. - A paper by Emile de Borchgrave gives a graphic sketch of the history of Etienne Douchan, Emperor of Servia, and the Balkan Peninsula in the fourteenth century, and of the events which led up to the battle of Kossovo, the grave of the liberty and greatness of Servia.

Cincinnati Society of Natural History.-.-In the October Fournal are two papcrs by U. P. James: one describing four new species of fossils from the Cincinnati group, the other treating of Conodionts and fossil annelid jaws.

\section{SOCIETIES AND ACADEMIES LONDON}

Mathematical Society, December ir.-J. W. L. Glaisher, F.R.S., President, in the chair.-The Rev. T. C. Simmons, Christ's College, Brecon, and Mr. W. J. Ibbetson, Clare College, were elected members. - Mr. Tucker read a paper on a group of circles connected with the nine-point circlc considerer as the locus of the intersections of orthogonal Simson lines. If $P L, P M, P N$ are the perpendiculars from any point of the circum-circle on the sides $B C, C A, A B$ of $A B C$, then $L M N$ is a Simson line: if $P O P^{\prime}$ be a diameter, then the Simson line $L^{\prime} M^{\prime} N^{\prime}$, corresponding to $P^{\prime}$, intersects $L M N$ at right angles in a point $C$, on the nine-point circle, which is also the inscribed circle of the tricusp, enveloper by the Simson lines. These properties were stated in a paper by Steiner ("Crelle," Band liii.). In the prescnt paper points $l, m, n$ are taken on $P L$, $P M, P N$, such that $L l=K . P L, M m=K . P M, N n=K \cdot P N$ It was shown that the lines $l m n, l^{\prime} m \prime^{\prime} n^{\prime}$ intersect at right angles on a system of circles whose centres lic on the line connecting the circum-centre and ortho-centre $(H)$ of $A B C$ that the sets of $Q$ points (as above) lie on another straight line through $I F$ : that the circles are inscribed in tricusps, the points of contact lying on three straight lines symmetrically situated and passing through $H$. In the special case of nulradius, i.e. when the $(K)$ circle becomes the ortho-centre, it was seen that the images of any point on the circum-circle with regard to the three sides lie on a straight line through $H$. $-\mathrm{Mr}$. Tucker then read parts of a paper by Mr. R. A. Roberts, cutitled "Notes on the Plane Unicursal Ouartic."-Two posthumous notes by the late Dr. Spottiswoode, P.R.S., were communicated, viz. on quadratic transformations, and to find whether a (certain quadratic transformation be possible.-The Treasurer (A. B 